\author{
(online) $=$ ISSN $2285-3642$ \\ ISSN-L = $2285-3642$ \\ Journal of Economic Development, Environment and People \\ Volume 9, Issue 2, 2020 \\ URL: http://jedep.spiruharet.ro \\ e-mail: office jedep@spiruharet.ro
}

\title{
Implementing Regulation regarding Minority Rights in Romania Special Overview of the Legal Frame of Romanian Law and Constitution
}

\author{
Flavia Lucia Ghencea ${ }^{1}$, Mihnea Claudiu Drumea $^{2}$ \\ ${ }^{1}$ phd, associate professor at Faculty of Juridical Sciences and Economics, Constanța, Spiru Haret University \\ ${ }^{2}$ phd, professor at Faculty of Juridical Sciences and Economics, Constan ța, Spiru Haret University)
}

\begin{abstract}
The general concept of non-territorial autonomy is analyzed in the specialized doctrine from various perspectives - considered, in fact, as its attributes - such as, cultural, linguistic, educational, traditional, and religious perspectives- all considering the identity of the minority group that lives in a majority community. The present paper, part of a larger research, proposes, on the one hand, an analysis of the legal framework regarding non-territorial autonomy in Romania - from the perspective of the regulations regarding the establishment, organization and functioning of the authorities with their role in the elections and the administrative structures at a local level and, whilst considering the role played by the minority groups in this framework. Because Romania has recently adopted a new fundamental regulation for the functioning of public administration - the New Administrative Code - which contains important regulations which have an impact on minorities' lives, another purpose of this research is to track how they are applied to the provisions on the linguistic rights of the national minorities included in Local Public Administrative Regulation. The objectives of this research will be, first, to use the data obtained in national reports and secondly, to make recommendations on the most efficient way in which the legislative norms regarding the protection of minorities can be applied, focusing on costs, human and financial resources.
\end{abstract}

Keywords: public administration, non-territorial autonomy, minorities, Administrative Code

JEL Codes: K10, K23, K38, K40

How to cite: Ghencea F.L., Drumea M.C. (2020). IMPLEMENTING REGULATION REGARDING MINORITIES RIGHTS IN ROMANIA. SPECIAL OVERVIEW OF THE LEGAL FRAME OF ROMANIAN LAW AND CONSTITUTION, Journal of Economic Development, Environment and People. 9(2) 2020 , DOI: https://doi.org/10.26458/jedep.v9i2.667

\section{General Thoughts regarding the Autonomy}

1.1. Addressing the autonomy from the local perspective, that of the community:

\footnotetext{
${ }^{1}$ Corresponding author: Tel +40241545015, E-mail address: flavia.ghencea@spiruharet.ro
} 


\author{
(online) $=$ ISSN $2285-3642$ \\ ISSN-L = 2285-3642 \\ Journal of Economic Development, Environment and People \\ Volume 9, Issue 2, 2020 \\ URL: http://jedep.spiruharet.ro \\ e-mail: office jedep@spiruharet.ro
}

The principle of local autonomy is the fundamental principle that governs the local public administration and the activity of its authorities;

It refers to the right of the administrative-territorial units to satisfy their interests without the interference of the central authorities, a principle that entails administrative decentralization;

The autonomy is a right, and decentralization is a system that implies autonomy (Autonomy is a political objective of decentralized governance).

In Romania, the local autonomy is regulated by the Constitution and the national legislation. Thus, it is a constitutional principle enshrined in Article 120 (), and a legal principle found in the administrative code (Vedinaș V., 2020);

The local autonomy is only administrative and financial, being exercised on the basis and within the limits of the law; it concerns the organization, functioning, competences and attributions as well as the management of the resources that, according to the law, belong to the community, the city or the county, as the case may be;

The characteristic of local autonomy is the distribution of decision-making power at the local level the possibility to take different measures without the approval of the central government;

Local autonomy represents not only a constitutional principle but also a way of organizing the administration of local authorities;

It is one of the most efficient forms of administrative self-management; ensuring a high degree of democracy, but also of the quality of social life.

Along with these many advantages, we also identify dangers - and we refer here to the selfregulation of autonomy - by law, a situation that can highlight the inequalities between local authorities. All these because Governmental processes can't be seen as discrete, centralized, or homogeneous (as we were used to seeing in the old nation-state model) but as asymmetrical, multicultural, and devolved into multiple jurisdictions (Nimni E., 2010).

\title{
1.2. European Legal Instrument:
}

At European level, the issue of minorities is one of the 8 "pillars" of a building of national identity, along with culture, religion, education, multilingualism, migration and youth. According this, EU has an entire legal frame, basically represented by several acts: The Framework Convention for the Protection of National Minorities, the European Charter of Local Self-Government - the only binding legal documents that set out well-defined obligations for EU member states, commitments that the Romanian state has transposed into national law.

The Framework Convention, who was signed by Romania in 1995 and ratified in 2007() - it requires the states to:

- promote the conditions that allow people belonging to national minorities to maintain and develop their culture;

- preserve the essential elements of their identity, namely religion, language, traditions, and cultural heritage;

- have the right to use the names in the minority's language, to use it unrestrictedly and to study in that language, to benefit from signs, inscriptions, and information in the respective language; 


\author{
(online) $=$ ISSN $2285-3642$ \\ ISSN-L = $2285-3642$ \\ Journal of Economic Development, Environment and People \\ Volume 9, Issue 2, 2020 \\ URL: http://jedep.spiruharet.ro \\ e-mail: office jedep@spiruharet.ro
}

\title{
2. Brief Presentation of the Minorities in Romania
}

According to the 2011 census, the minority population represents about $11 \%$ of the total of 20.1 million inhabitants.

The most important minorities in Romania are:

- Hungarian minority - 1.23 million inhabitants (about $58.9 \%$ of total minorities);

- Roma minority - 0.62 million (29.8\% from minorities);

- Ukrainians - 50.9 thousand inhabitants (2.44\% of minorities);

- Germans - 36 thousand (1.73\%);

- Turks - 27.7 thousand (1.33\%);

- Russians - Lippovans - 23.49 thousand (1.13\%);

- with less than $1 \%$ share (each) of minorities (20 thousand inhabitants, or less) - Tatars, Serbs, Slovaks, Bulgarians, Croats, Greeks, Jews, Italians, Poles, Czechs, and other minorities.

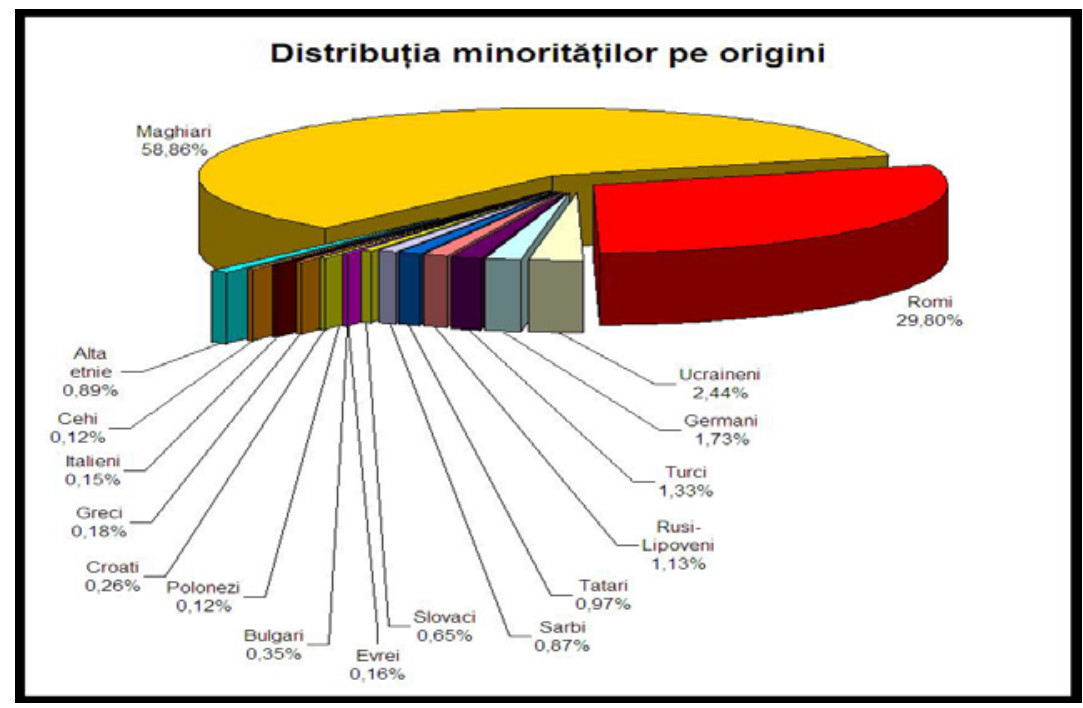

Fig. 1: Minorities distribution by origins

Source: Recensământul populației și locuințelor, 2011,Population and Housing Census, 2011, ISPMN http://www.rador.ro/2017/12/18/analiza-minoritatile-nationale-din-romania-intre-aspiratii-si-realitati-2/ 


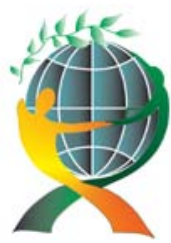

\author{
(online) $=$ ISSN $2285-3642$ \\ ISSN-L = $2285-3642$ \\ Journal of Economic Development, Environment and People \\ Volume 9, Issue 2, 2020
}

URL: http://jedep.spiruharet.ro

e-mail: office jedep@spiruharet.ro

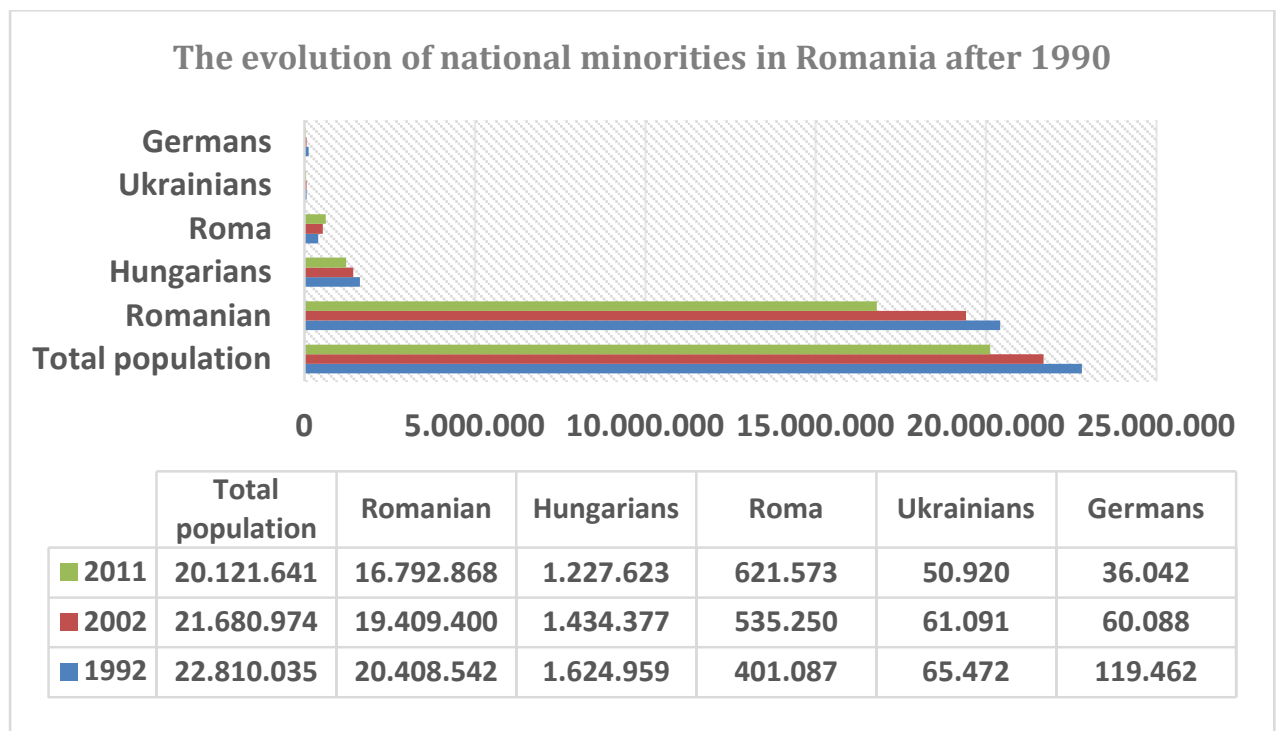

Fig. 2: The evolution of national minorities in Romania,

Recensământul populației și locuințelor, 2011, Population and Housing Census, 2011

\title{
3. A New Approach for Romania - the Status of Personal Autonomy
}

The question of how governments manage the situation of ethnic diversity is fundamental for the future of democracy in Europe. The way this question is articulated and addressed has changed significantly in last period. On the other hand, is important how European governments and social actors respond to problems of regional security, domestic political contestation, and economic well-being (Czsergo. Z., Vangelov O., Balasz V., 2018). This, from all points of view.

In 2005 , the Hungarian community in Romania came up with a unique legislative proposal, namely, a draft law that wanted to regulate a new concept of "personal autonomy." The proposal was based on the idea of an institutional mechanism that would provide minorities with full autonomy regarding schooling, publications, and media or heritage administration in the mother tongue. The money would continue to come from the state budget, but their administration would no longer be done through the entitled ministries, such as the Ministry of Education, the Ministry of Culture and Religious Affairs, but through a specific set up body, with executive management and a Council constituted by direct elections. The Venice Commission noticed the discriminatory nature of the electoral legislation in 2005 and the project was blocked.

Although, in the Romanian political circles, there are no arguments against cultural or personal autonomy, as Romanians are considered tolerant and welcoming people, the idea of non-territorial autonomy arouses confusion in Romania.

In order for the institutions of the autonomy to carry out their activity without difficulty, it is necessary as a rule for minorities to participate directly in the exercise of central power (Levente Salat, 2014). 


\author{
(online) = ISSN $2285-3642$ \\ ISSN-L = $2285-3642$ \\ Journal of Economic Development, Environment and People \\ Volume 9, Issue 2, 2020 \\ URL: http://jedep.spiruharet.ro \\ e-mail: office jedep@spiruharet.ro
}

\title{
4. The Legal Framework Regarding the Non-territorial Autonomy in Romania - from the Electoral Legislation Regulations' Perspective
}

The participation of ethnocultural minorities in political decision making is an important aspect of minority rights. Electoral systems, however, do not always allow this through elections, whether it is representation at the national or local level. Thus, different procedures have emerged to facilitate this political representation in the case of national minorities.

Even Non-territorial autonomy (NTA) has acquired a variety of meanings ranging from a vague principle (a 'thin' approach) to a distinct structural feature of an organization (a 'thick' approach) (Osipov, 2018), we remain, throughout this study on analyzing the phenomenon from the perspective of observations on minority "groups" or "communities".

The participation of ethnocultural minorities in political decision making is an important aspect of minority rights. Electoral systems, however, do not always allow this through elections, whether it is representation at the national or local level. Thus, different procedures have emerged to facilitate this political representation in the case of national minorities.

Romania is one of the $\mathbf{1 7}$ states of the world whose legislation provides the possibility of gaining seats in the national parliaments for representatives of national minorities and one of the $\mathbf{3 3}$ states in which minorities succeed gaining seats casting candidates in the elections;

The legal representation of the national minorities was decided by the electoral law adopted by the Provisional Council of National Unity for the elections of May 20, 1990 and approved by the Constitutions of 1991 and 2003;

All fundamental rights are guaranteed by the Constitution and other national laws to the ethnic minorities in Romania, including the use of the mother tongue in the public administration, education, media, the right to participate in the political life, etc., any form of discrimination or undermining the rights of national minorities' members being prohibited;

Romania ensures the participation of national minorities in the decision-making process by representation in Parliament, ensuring an ex-officio seat in the Chamber of Deputies for each national minority that does not obtain representation otherwise. Of the 20 national minorities in Romania, 19 are represented on the constitutional basis, the exception is the Hungarian Democratic Union of Romania, which obtains more votes than the electoral limit;

“Citizens' organizations belonging to national minorities, which do not accumulate the number of votes to be represented in the Parliament, have the right to one deputy seat, under the conditions of the electoral law. Citizens of a national minority can only be represented by one organization"

(The Constitution of Romania, Article 62, § 2)

The evolution of number of seats in Parliament for National Minorities in Romanian look like above:

- In 1990, based on the electoral law prior to the Constitution (Article 4 of Decree-Law 92/1990) in the Chamber of Deputies 12 minorities were elected, apart from the UDMR;

- In 1992, there were 13 MPs representing different minorities, besides the UDMR;

- In 1996- 15 seats;

- In 2000 and 2004 there were 18; seats

- $\quad$ In 2008 and 2012 - 17 seats; 


\author{
(online) $=$ ISSN $2285-3642$ \\ ISSN-L = 2285-3642 \\ Journal of Economic Development, Environment and People \\ Volume 9, Issue 2, 2020 \\ URL: http://jedep.spiruharet.ro \\ e-mail: office jedep@spiruharet.ro
}

- In 1992, the law required a minimum of $5 \%$ of the total number of votes necessary to elect a deputy;

- In 2004, the number of votes required was raised to $10 \%$ of the votes for the election of a deputy, which led to a situation where a deputy could be elected by 1,336 votes in 1992 , or by 2,841 votes in 2004.

- In the 2016-2020 legislature, no less than 17 minorities are represented in the Parliament, apart from the UDMR, which exceeds the electoral minimum of $5 \%$ and has its own parliamentary groups.

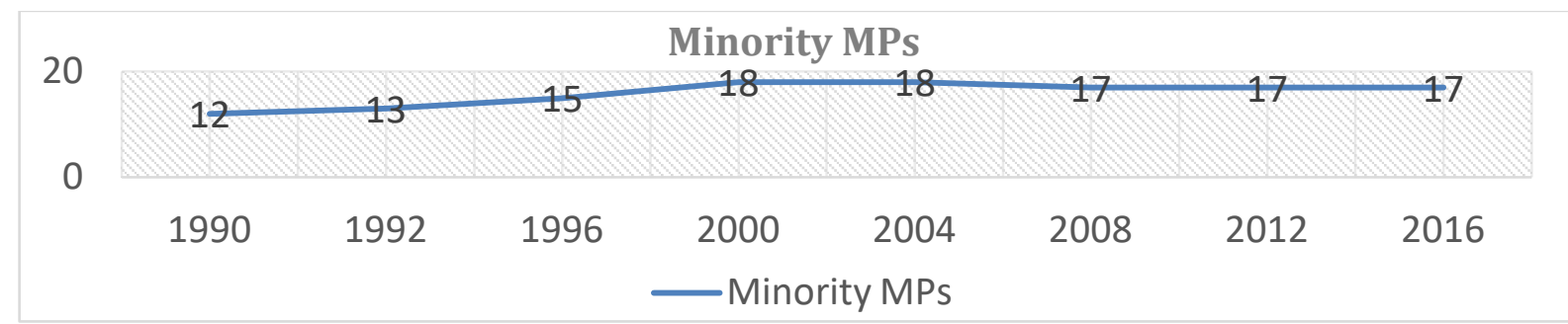

Fig. 3: Minority's representation in Romanian Parliament According to the 2016 national election

The revised form of the Constitution, in force since 2003, did not bring about fundamental changes in the rights of national minorities, but added two dimensions to their social rights: the right to use the mother tongue in court (Article 182/2) and in the public administration (Article 120);

In terms of electoral legislation, Romania has amended the normative framework to exempt minorities from achieving the electoral threshold similar to the one existing for political parties so that they can be represented in the Parliament, on a number of dedicated seats - except a minority that has a political party that meets the legal threshold for accession in Parliament will have a number of mandates corresponding to the votes obtained (in Romania it is only the case of the Hungarian minority);

According to the Law on the Election of the Senate and the Chamber of Deputies, (Article 56 of the law 208/2015):

"citizens' organizations belonging to a national minority, legally constituted, who did not obtain at least one deputy or senator's mandate in elections have the right to a deputy seat if they have obtained, throughout the country, a number of votes equal to at least $5 \%$ of the average number of valid votes cast in the country for the election of a deputy"

Thus, the political representation of minorities beyond the demographic obstacles was secured, leading to the existence of a parliamentary political group of national minorities in the Chamber of Deputies, organized like all other parliamentary groups and whose members engage in all parliamentary activities (in commissions or representation activities in interparliamentary or regional bodies, etc.)

\title{
5. Tracking the Implementations of the Provisions Regarding the Linguistic Rights of National Minorities Included in the Local Public Authorities By-laws
}




\author{
(online) $=$ ISSN $2285-3642$ \\ ISSN-L = $2285-3642$ \\ Journal of Economic Development, Environment and People \\ Volume 9, Issue 2, 2020 \\ URL: http://jedep.spiruharet.ro \\ e-mail: office jedep@spiruharet.ro
}

Many countries protect minority languages in aim to preserve culture and education of minorities. This, mostly by signed relevant international standards on linguistic rights for minorities. Neither system is very transparent, nor comprehensive. This create many time consternation and dissatisfaction among the national minorities (Maloy T. 2015).

One of the major developments in the field of minority protection in Romania is the significant change in the field of linguistic policies towards minorities: a shift from the exclusive promotion of the Romanian language (specific to the communist regime) to a line of public policies that promotes (and supports) the allocation of significant sociolinguistic functions to the minority languages (in formal education, administration, justice, other spheres of public life), as Romania assumed obligations towards the international community that emerged by adhering to some international treaties and reference conventions in the field of linguistic rights promotion of minorities.

It should be mentioned as well, that during the communist period exclusivism was not absolute, as the national TV broadcasted programs in Hungarian and German.

\title{
6. Conclusion
}

We appreciate that Romania guarantees to all minorities the right to free expression and information in the mother tongues, strengthening a model of coexistence and integration according to European values.

Short examples to support our conclusions:

The existence of an authority dealing with the minorities in Romania, the Institute for the Study of the Problems of the National Minorities, an administrative institution subordinated to the Government of Romania, having as objectives the study and the inter and multidisciplinary research of the preservation, development and expression of ethnic identity, sociological, historical, cultural, linguistic, religious or other aspects of national minorities and other ethnic communities in Romania;

Each national minority has its own journal or a publishing house:

- "Polonus" and "Mały Polonus" journals published by the Polish community;

- "Macedoneanul", published by the Macedonian minority;

- "Zorile" and "Aurora" Russian minority's journals;

- "Cuvântul nostru", "Viața literară" and "Vestitorul de Timişoara", published by the Serbian minority;

- "Qaradeniz-Marea Neagră" Tatars' minority journal;

- "Hakses" published by the Turkish Democratic Union;

- "Vilneslovo", "Ucrainskyi visnyk", "Curierul ucrainean" Ukrainian minority's journals;

- "Asul de Treflă" published by the Roma Party.

The Jewish community coordinates a Jewish Center for Publishing and Publicity, a Center for historical studies, libraries, a history museum, has the "Hasefer" publishing house (participating in over 100 book fairs) and a landmark publication, "Reality Hebrew."

The Greek minority has a publishing house and a bilingual newspaper, "Elpis" and is highly appreciated for organizing the international neo-Greek Olympic Games.

In a study dedicated to the minorities of South-Eastern Europe, an inventory of more than 150 institutions and cultural associations of Hungarians, with contact data, was identified existing at that time 


\author{
(online) $=$ ISSN $2285-3642$ \\ ISSN-L = $2285-3642$ \\ Journal of Economic Development, Environment and People \\ Volume 9, Issue 2, 2020 \\ URL: http://jedep.spiruharet.ro \\ e-mail: office jedep@spiruharet.ro
}

in Romania, to which were added 6 associations from the media, 18 radio stations, 14 TV stations with Hungarian programs, over 40 publishers and about 50 central, county and local daily newspapers.

The German minority supports an important cultural and civic activity (a central German-language newspaper is published in Bucharest, besides, regularly appearing, 3 political weekly journals and two cultural magazines.

This are only few examples, there are more modality that people from minorities communities can preserve their identity, even we talk about culture, tradition, or history.

We can see below, an ethnic map of Romania, official one, based on 2011 census data - the latest census organized in Romania:

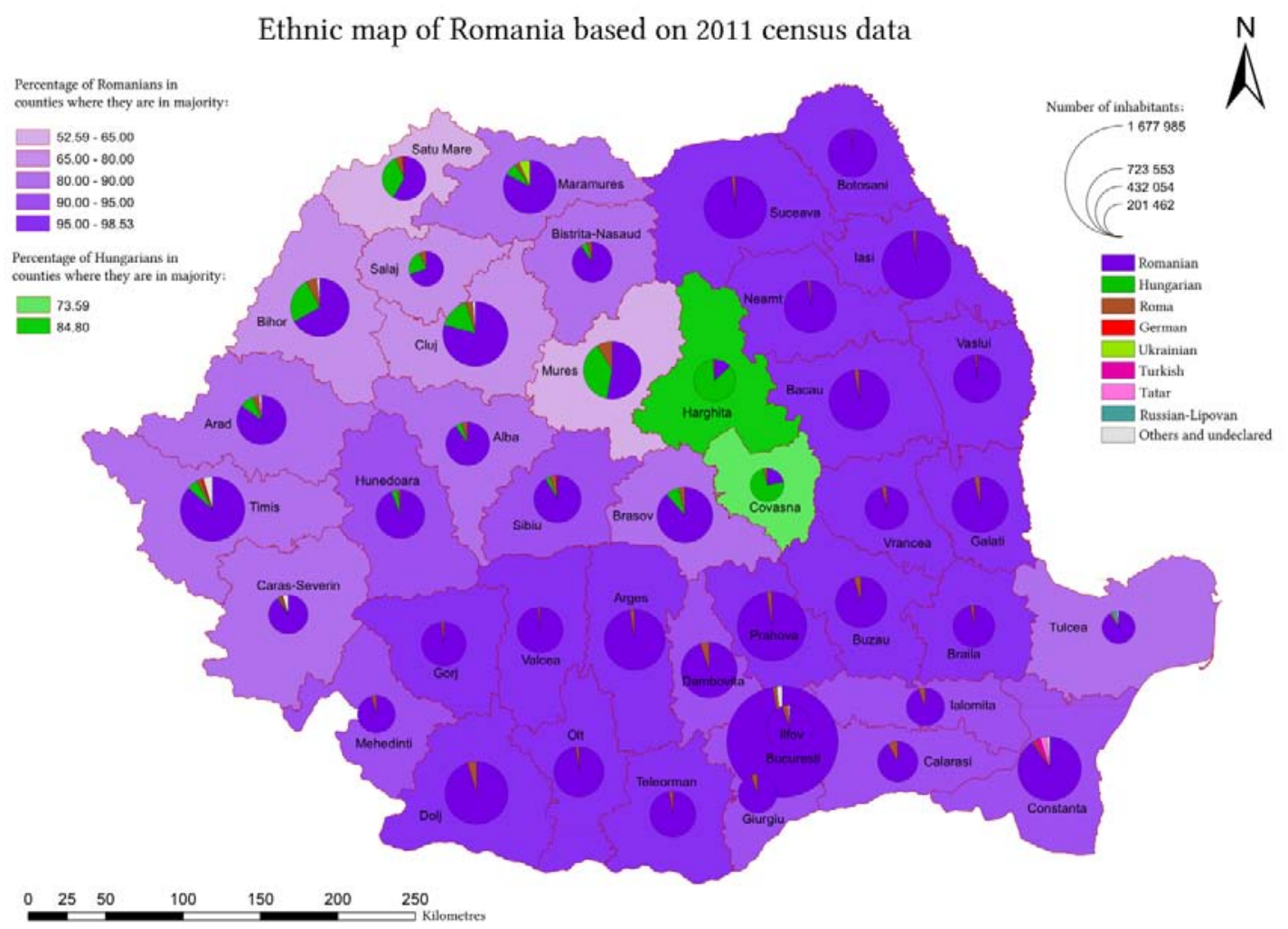

Fig. 4: Ethnic map of Romanian population according to 2011 census Source: https://commons.wikimedia.org/wiki/File:Harta_etnica_2011 JUD.png

\title{
7. Acknowledgements
}

This paper represents a study developed in one COST Action - AC18114 - ENTAN. Part of this Action, as a member of Working Group 1 - Non-territorial autonomy - Legal and political aspects, and MC member, we were able to present some aspects regarding the Romanian approach regarding minorities at the Conference organized by the Action in November 2019, at Belgrad: Non-Territorial Autonomy as a Form of Plurinational Democracy: Participation, Recognition, Reconciliation. 


\author{
(online) $=$ ISSN $2285-3642$ \\ ISSN-L = $2285-3642$ \\ Journal of Economic Development, Environment and People \\ Volume 9, Issue 2, 2020 \\ URL: http://jedep.spiruharet.ro \\ e-mail: office jedep@spiruharet.ro
}

So, we are proud to thank, with deference, to the scientific committee of the conference and especially to Professor Ivan Dodovski, Chair of ENTAN; thanks for the support and for the opportunity to be part of a high-level event.

\title{
8. References
}

[1] Salat L., Novak C.Z., Ethnicity, Nationalism and the Minority Regime in Lavinia Stan, Diane Vancea, eds. PostCommunist Romania at Twenty-Five, Lanham: Lexington Books, 2015, pp.63-85;

[2] Nimni Ephraim, Nationalism, Ethnicity, and Self-Determination: A Paradigm Shift in Keith B., O’Neill S., eds. After the Nation? - Critical Reflections on Nationalism and Postnationalism, Palgrave Macmillan, 2010, pp.21-37;

[3] Tove Maloy, Sonya Wolf, Linguistic Minority Rights in the Danish-German Border Region: Reciprocity and Public Administration Policies, in International Journal on Minority and Group Rights, Brill/Nijhoff, 2016, 23(4):485-504;

[4] Csergő, Zsuzsa; Vangelov, Ognen; Vizi, Balázs. Minority Inclusion in Central and Eastern Europe. Intersections. East European Journal of Society and Politics, [S.l.], v. 3, n. 4, jan. 2018; pp.5-17;

[5] Osipov Alexander, Can "Non-territorial Autonomy serve as analytical term? Between "Thick" and "Thin" approaches, in International Journal on Minority ang Group Rights, vol 25: Issue 4, Brill/Nijhoff, 2018, pp.621-646

[6] Vedinaș Verginia, Drept administrativ, Universul Juridic Publishing House, Bucharest, 2020;

[7] Romanian Constitution, revised and adopted by national referendum on 2003, republished in Official Gazette no. 758/29.22.2003;

[8] Administrative Code of Romania - Government Emergency Ordinance no. 57, published in Official Gazette no. 555/5.07.2019;

[9] Law 208/2015 regarding the election of the Senate and the Chamber of Deputies, as well as for the organization and functioning of the permanent electoral authority, published in Official gazette no. 553/24.07.2015; 